\title{
Vernacularization as Governmentalization: the Development of Kurdish in Mandate Iraq
}

\author{
Michiel Leezenberg
}

\section{Introduction}

In recent years, the notion of vernacularization has gained a wider currency, thanks in particular to Sheldon Pollock's impressive comparative explorations of what he calls the Sanskrit and Latin cosmopolitan orders. ${ }^{1}$ It denotes the shift towards new written uses of vernacular languages that had hitherto exclusively been used for spoken communication. The shift from Latin to Romance languages such as French, Italian, and Catalan around the year $1000 \mathrm{CE}$ is probably the best known and best documented example of vernacularization; rather less familiar, but hardly less dramatic, is the emancipation of vernacular languages such as Telugu and Kannada with respect to Sanskrit in the Indian subcontinent, which likewise occurred toward the end of the first millennium CE.

Although the work of Pollock and his associates focuses on the Indian subcontinent, it has also provoked comparative questions, such as whether similarly cosmopolitan orders and vernacularization processes may also be found elsewhere. Over the past years I have been working on vernacularization in the early modern and modern Ottoman empire, with many surprising results. This empire knew a complex linguistic order, dominated - even among the Muslim majority of the population - by not one but three languages: Arabic for legal and religious learning, Persian for high literature, and Ottoman Turkish for the administration. If one includes the Christian population groups in the empire, the linguistic situation becomes even more complex: classical liturgical languages such as koinè Greek, Classical Armenian (Grabar), Syriac, and Old Church Slavonic were still used among the Christians, but for liturgic and literate purposes only, and were incomprehensible to the vast majority of their respective congregations. Ottoman Jews generally used the "sacred language"

1 See in particular Sheldon Pollock, "Cosmopolitan and Vernacular in History," Public Culture 12 (2000): 591-625 and The Language of the Gods in the World of Men: Sanskrit, Culture, and Power in Premodern India (Berkeley: University of California Press: 2006). 
(lashon ha-qodesh) for liturgical purposes, but spoke a wide variety of local languages.

The most important empirical finding here was that virtually all population groups in the Ottoman empire appear to have witnessed a phase of vernacularization in the eighteenth and early nineteenth centuries. I will briefly discuss this process below, as I think it is highly relevant, not to say essential, to a better understanding of developments in the twentieth century. I also have a methodological axe to grind, however: I would like to propose a genealogical approach to vernacularization, which takes into account the roles of different forms of knowledge and power. Such an approach implies that one should take a long-term view to get a better grasp of the local dynamics involved. I would also like to suggest that, next to vernacularization, one should pay attention to what may be called the governmentalization of language, that is, the process of language becoming an object of knowledge and governmental concern. Coined by Foucault, the notions of governmentality and governmentalization have a number of conceptual and descriptive advantages. ${ }^{2}$ Descriptively, they focus attention on how language has become an object of both knowledge and government; they also imply a shift away from the state and the associated view of power as sovereign, law-like and repressive. It should be noted, however, that Foucault himself never extended these notions to questions of language, nor did he ever present or even sketch out a genealogical approach to the modern linguistic sciences.

Looking at questions of language and national identity in terms of governmentality may help us look for answers in places and institutions other than the state, and in periods preceding modern state formation. It may also help to redirect our attention to dimensions of power and knowledge in the process of vernacularization: in the wake of becoming mediums for literate and learned communication, vernacular languages simultaneously became objects of study (primarily in the form of written, and in some cases printed, grammars) and objects of governmental concern (primarily captured in the - radically novel - propagation of native language education). These two processes of vernacularization and governmentalization may, but need not, coincide, so it is better to keep them analytically separate.

Hence, I would like to suggest a comparative, global, and interactional approach, which systematically abstracts away from, and thus questions, underlying assumptions of either a methodologically or a politically nationalist character - assumptions that still pervade much writing on the topic. By

2 Michel Foucault, Securité, territoire, population: Leçons au Collège de France, 1978-1979 (Paris: Gallimard/Seuil, 2004). 
studying the development of a single language in isolation, one risks overlooking common and converging patterns, and taking for granted the nationalist identification of an imagined nation with a reified language that should be traced historically and scrutinized conceptually in the first place. I hope to do so in a very preliminary manner below, with a focus on the development of Kurdish in Mandate and Monarchical Iraq. ${ }^{3}$

Ottoman Vernacularization: the Role of Local Philologies ${ }^{4}$

As noted above, it was Pollock's work in particular that called attention to patterns of vernacularization in different parts of the world. Pollock has also pointed to the role of philology, broadly characterized as the scholarly study of texts and/or languages, and of grammar and literature, in these processes. For Western and Central Europe, the importance of modern philology for the rise of romantic nationalism has been studied in great detail. Relatively little attention has been paid, however, to vernacularization in the early modern Ottoman empire and to the role of local philological traditions in the rise of Ottoman nationalisms. Moreover, the few studies on early modern Ottoman learning tend to focus on works written in the cosmopolitan languages, such as Arabic and Ottoman Turkish. ${ }^{5}$ Yet, in the late seventeenth and eighteenth centuries one may observe a significant shift in these traditions towards the use of local vernaculars.

Next to the use of Arabic as the language of religious learning and Ottoman Turkish as the language of administration, the Ottoman empire also used Persian as the main language of literary civilization. As such, it plays a special role not only in the early modern Ottoman empire, but also in a far wider, and still relatively poorly understood, cosmopolitan constellation. This cosmopolitan constellation centred around Classical Persian-language poets such

3 For empirical data this paper leans heavily on Amir Hassanpour's indispensable overview, Nationalism and Language in Kurdistan, 1918-1985; I am also indebted to kak Amir for providing me with digital versions of some of his later writings. Thanks are also due to Hassan Ghazi, Ismail Barzinji, Kadri Ylldırım, and numerous others who have over the years shared with me their valuable insights on the linguistic situation in Iraqi Kurdistan.

4 A different version of this paragraph was included in Michiel Leezenberg, "The Vernacular Revolution: Reclaiming Early Modern Grammatical Traditions in the Ottoman Empire," History of Humanities 1,2 (2016): 251-275; it is reprinted here by permission of the editors.

5 See e.g. Khaled el-Rouayheb, Islamic Intellectual History in the Seventeenth Century: Scholarly Currents in the Ottoman Empire and in the Maghreb (Cambridge: Cambridge University Press, 2016); Ahmad Dallal, Islam before Europe: Traditions of Reform in Eighteenth-Century Islamic Thought (Chapel Hill: University of North Carolina Press, 2018). 
as Ferdowsi, Nizami, Jami, Rumi, Hafez, and many others. Originating on the Iranian plateau, this Persian-language tradition came to dominate all parts of the Islamic world where Arabic was not the spoken language of at least a substantial part of the population; for centuries, this cultural sphere extended all the way from the Balkans to Central and South Asia. Marshall Hodgson has qualified it as "Persianate," since it did not necessarily involve Classical Persian as the written, and in some cases spoken, language of courts and polite letters, but could also revolve around local vernacular languages that displayed a considerable Persian influence. ${ }^{6}$ Linguistically informed studies of this cosmopolitan tradition (as of the other traditions mentioned above) are few and far between; at present we simply lack overviews that do justice to this cultural sphere as a coherent linguistic and literary whole, which nonetheless displays not only great regional variation and development, but also numerous local vernacular offshoots. ${ }^{7}$

More recently, Shahab Ahmad has characterized this space as the "Balkans to Bengal complex," also calling attention to its Persian-language religious and literary dimensions. Hamid Dabashi has likewise described this cosmopolitan and, as he calls it, humanist order in more detail; but he narrowly focuses on Persian-language literary production, at the expense of Persian-inspired vernacular literatures such as those in Pashto, Kurdish, and Baluchi, erroneously asserting that the latter only knew oral traditions. ${ }^{8}$

To some extent, Persianate and Arabic influences overlapped; but whereas Arabic was, and remained, the primary if not sole language of religious learning, Persian became the dominant language of literary expression, government, and mysticism. Initially, the Turkic dynasties in Anatolia, including the Ottomans, wrote their official correspondence as well as their poetry in Persian; but by the sixteenth century, Ottoman Turkish had largely replaced Persian as the language of the Ottoman bureaucracy, and had emerged as a language of refined courtly poetry in its own right. Despite this shift, however, Turkish never wholly sidelined Persian as a language of high literature; and in any case, official and literary uses of Turkish were and remained replete with Persian (and, of course, Arabic) loan words and loan constructions.

6 Marshall Hodgson, The Venture of Islam, vol. 2: The Expansion of Islam in the Middle Period (Chicago: University of Chicago Press, 1974), 293.

7 For a summary overview, see Bert Fragner, Die 'Persophonie': Regionalität, Identität, und Sprachkontakt (Berlin: Das arabische Buch, 1999).

8 Shahab Ahmed, What is Islam? (Princeton NJ: Princeton University Press, 2016), esp. Ch. 1; Hamid Dabashi, The World of Persian Literary Humanism (Cambridge: Harvard University Press, 2012), esp. 331n. 
Thus, the vernacularization that occurred in the early modern Ottoman empire is distinct from the comparable processes in the Latin and Sanskrit cosmopolitan orders in that it took place in a cosmopolitan setting that was itself systematically multilingual, involving Ottoman Turkish as well as Arabic and Persian as written languages, not to mention the classical written languages of Christian minorities such as the Greeks and the Armenians. From the late seventeenth century onwards, local vernaculars increasingly started to be used for literate purposes that had until then remained the reserve of these classical and cosmopolitan languages; here, I can only present a bird's eye view of this rich and complex process. ${ }^{9}$

The seventeenth- and eighteenth-century Ottoman vernacularization occurred most visibly among the Christian subject populations in the western part of the empire, thus lending some initial plausibility to the idea that this innovation had Western European origins. First, authors such as Iosipos Moisiodax and Adamantios Korais pioneered the emancipation of vernacular modern Greek from the long-standing hegemony of koinè Greek in education. Second, among the Ottoman Armenians, a spoken - and increasingly also written and printed - supraregional "civil language" (called k'aghak'akan or askharhorên) emerged, which was distinct both from the classical language (or Grabar) that had been in written use since the 5 th century CE and from locally spoken dialects. Third, the second half of the eighteenth century also saw a vernacularization of the Slavic languages, in the first attempts to write literary texts in Serbian and Bulgarian. Thus, in his 1762 Istoriya Slavyanobolgarskaya, Paisii Hilendarski fulminated against increasing Greek efforts at linguistic assimilation in the orthodox church, and Sofronij Vracanski consciously wrote his memoirs in what he calls the "Slavo-Bulgarian" vernacular. Fourth, Romanian, or "Wallachian" as it was generally called (Greek: vlakhos, Turkish eflak), emerged as a written language, following the translation of the Bible into Romanian in 1688 and the pioneering literary and learned works by polymath Dimitrie Cantemir around $1700 .{ }^{10}$ These vernacularizations among Christians living in various parts of the Ottoman empire appear to reflect local religious and possibly socioeconomic dynamics at least as much as any theological contacts with Western European

$9 \quad$ For a more detailed account, see Leezenberg, "The Vernacular Revolution." I hope to present a more detailed account in From Coffee House to Nation State (in preparation).

10 On Greek vernacularization, see Peter Mackridge, Language and National Identity in Greece, 1766-1976 (Oxford University Press, 2009); on Armenian, see Marc Nichanian, Ages et usages de la langue arménienne (Geneva: Éditions Entente, 1989); on Romanian, see Werner Bahner, Das Sprach- und Geschichtsbewusstsein in der rumänischen Literatur von 1780-1880 (Berlin: Akademie-Verlag, 1967). 
Catholics, Protestants, or Enlightenment thinkers, or mercantile contacts with Western European merchants.

The assumption that Western European influences were the driving force behind these developments becomes even harder to maintain in the light of similar shifts among Muslims in the Balkans and among Muslim population groups further East. First, the late seventeenth and early eighteenth centuries witnessed the emergence of vernacular Persianate poetry among Muslims in Ottoman Bosnia and Albania." Both Bosnian Muslim poets and Albanian bejtexhinj, or "bayt poets," such as Muçizade, Nezim Frakulla, and Hasan Zyko Kamberi, were very conscious of the novelty of composing learned literature in their native tongue. Their work, moreover, was remarkably isolated from similar vernacularizing efforts among Catholic and Orthodox authors. Earlier, a number of Albanian works had been written by Catholic priests, but these had not reached the orthodox and Muslim Albanian-speaking population in Ottoman territory. Thus, for all we know the bejtexhi tradition is a purely local outgrowth. Likewise, a number of works were written by Muslim authors in "Bosnian," a South Slavic dialect written in Arabic script, most famously perhaps the Potur shahidiyya, a rhymed Turkish-Bosnian vocabulary from the seventeenth century already mentioned by Evliya Çelebi. Local Orthodox and especially Catholic Christians had written texts in quite similar Slavic dialects, but these, too, have apparently remained unknown among Bosnian Slavic-speaking Muslims. Indeed, the different vernacular traditions that emerged in early modern times appear to have been segregated along denominational or sectarian lines, and betray little if any sense of nationality as defined in primarily or exclusively linguistic terms.

Second, and perhaps surprisingly, even the language of administration, Ottoman Turkish, went through a vernacularization of sorts in that in learned poetry as well as bureaucratic prose one may see a conscious movement towards linguistic simplification, and to a register of Turkish closer to the language spoken by the Istanbul population than to the highly learned and virtually incomprehensible language of the küttab or "scribes," i.e., the literate Ottoman officials. ${ }^{12}$ This particular vernacularization seems exceptional in that it was primarily a top-down process driven by parts of the state apparatus.

11 On early Albanian literature, see Robert Elsie, "Albanian Literature in the Moslem Tradition: Eighteenth and Early Nineteenth Century Albanian Writing in Arabic Script," Oriens 33 (1992): 287-306; on Persianate Bosnia poetry, see in particular Seifuddin Kemura and Vladimir Corovic. Dichtungen bosnischer Moslims aus dem XVII., XVIII., und XIX. Jahrhundert (Sarajevo, 1912).

12 See in particular Serif Mardin, "Some Notes on an Early Phase in the Modernization of Communication in Turkey," Comparative Studies in Society and History 3 (1961): 250-271. 
Third, and most directly relevant to our purposes, in the empire's remote Eastern provinces the Kurds witnessed a significant vernacularization from the late seventeenth century onwards. ${ }^{13}$ Most importantly, in 1695 Ehmedê Xanî authored the first-ever mathnawi poem in Kurmanjî or Northern Kurdish, the tale of the two ill-fated lovers Mem and Zîn, in a self-consciously innovative attempt to write learned poetry in the local vernacular "for the sake of the illiterate masses" ( ji boyî âmề). ${ }^{14}$ Indeed, his main aim appears linked to learning: he wrote his poem, he famously said, "so that people will not say that the Kurds are without learning, principle, or foundation" (da ko khelq-i nabêjitin ko ekrad/bê ma'rifet in, bê esl û binyâd). ${ }^{15}$ Unlike Ottoman Turkish vernacularization, this shift to Kurdish appears to have taken place primarily in the smaller rural medreses rather than in the prominent urban centres of learning, which were rather closer to Ottoman official culture. Moreover, it shows few if any signs of patronage from local courts, and thus appears to have been more of a bottom-up process.

On the whole, this Ottoman vernacularization involved works of learning as much as literary texts. Often, however, the two genres overlap or even coincide. Thus, Xanî also wrote several Kurdish-language works in rhymed verse expressly designed for beginning Kurdish-speaking medrese pupils, such as the Nûbihara piçûkan, an Arabic-Kurdish glossary, and the Eqîdeya Îmanê, a small catechistic text. The vernacularization of Kurdish also involved prose works of learning, such as Elî Teremaxî's Tesrîfa Kurmanjî and Yûnus Khalqatînî's Terkîb $\hat{u}$ zurûf, both presumably dating from the eighteenth century, which deal with, respectively, the morphology (sarf) and syntax (nahw) of Arabic. Importantly, this vernacularization involved not only new literate uses of vernacular languages, but also new linguistic ideologies that present vernaculars as eloquent, expressive and worthy of high literature. One might even argue that they may likewise be accompanied or followed by innovations in linguistic structure, primarily through the regimentation and codification of languages in written grammars. ${ }^{16}$ We will return to this point below.

\footnotetext{
13 See Michiel Leezenberg, "Eli Teremaxi and the Vernacularization of Medrese Learning in Kurdistan," Iranian Studies 47 (2014), 713-733.

14 Ehmedê Xanî, Mem û Zîn (ed. J. Dost) (Avesta Yayınları, 2010 [1695]), bayt 239.

15 Xanî, Mem û Zîn, esp. 141.

16 Pollock, "Cosmopolitan and Vernacular," 612, briefly mentions the changing languageideological correlation between language and community and the linkage between vernacular language and political power, but does not otherwise address questions of linguistic ideology.
} 
As the above already suggests, it was the Northern dialect of Kurdish, or Kurmanjî, which in the eighteenth century underwent the most significant vernacularization. Subsequently, however, it was the "Central" Sulaimaniya dialect, or Soranî Kurdish, which became the main written variety of Kurdish in Iraq. This shows the contingent and non-linear character of many of these developments. The central dialect only started to be written around 1800; and prior to the publication of periodicals such as Têgeyishtinî Rastî and Pêshkewtî in the early twentieth century, it was hardly if at all used for written purposes other than poetry. Thus, there was no good linguistic reason for promoting this particular dialect to the status of a written standard over others; rather, its development - bumpy, uneven, and contested as it was - was due not to inevitable structural but to contingent political factors. Before we can address these, let us briefly trace the development of Soranî.

Roughly, three distinct kinds, or periods, of vernacularization of Kurdish may be distinguished. First, there is the vernacularization of Hawramî or, as Western orientalists have usually called it, Goranî. This process occurred quite early: starting around the fifteenth century, a variety of the Hawramî or Goranî dialect spoken in the border area between the Ottoman and Safavid empires came to be used, primarily by literate poets associated with the local Erdelan court. However, this dialect, or koinè, was not simply a 'court language'; it apparently did not replace Persian as the main language of administration, official correspondence, or - possibly - medrese education. Rather, this koinè was used primarily for learned and popular poetic purposes. Significantly, local poets did not call it "Goranî" or "Hawramî," but "Kurdî." The term "Goranî," not to mention the more far-fetched speculation about their origins and their alleged linguistic, national and/or racial differences with respect to 'Kurds proper,' appear to be primarily the creation of Western orientalists. ${ }^{17}$ In short, the vernacularization of Hawramî appears to have been restricted to poetic and, possibly, didactic works; subsequently, Hawramî was to be eclipsed by other dialects. ${ }^{18}$

The second wave of Kurdish vernacularization has already been described above. From the late seventeenth century, introductory textbooks in the Kurmanjî dialect became quite widespread among the medreses of Northern

17 See e.g. Vladimir Minorsky, "The Gûrân," вsOAS XI (1943): 75-103; David N. MacKenzie, "The Origins of Kurdish," Transactions of the Philological Society (1961): 68-80.

18 Local historian and literary scholar Hama Hewrami claims that education in this region was generally in Persian rather than any variety of Kurdish. Interview, Erbil, Spring 2014. 
Kurdistan. Works such as Mullah Bateyî's Mewlûd, Ehmedê Xanî's Nûbihara piçûkan and Eqîdeya Îmanê, Eli Teramaxî's Tesrîfa Kurmancî, and Mullah Yûnus Xalqatînî's Terkîb $\hat{u} z u r u \hat{f}$, became part of the rêz or curriculum of medreses as far apart as Diyarbakir, Hakkari and Beyazid. More advanced literary texts, such as Milayê Cezîrîs Dîwan and Ehmedê Xanî's mathnawî poem, Mem $\hat{u} Z \hat{i n}$, were not strictly part of the curriculum, but appear to have been widely read by Kurdish medrese pupils. These texts seem to have been widely used among rural medreses in Northern Kurdistan until quite recently. ${ }^{19}$

Third, one may witness the vernacularization of the Sulaimaniya dialect, or Soranî as it has been called since Hajî Qadirî Koyî. This process started much later than the other two, around $1800 \mathrm{CE}$; it also appears to have centred rather less around medrese life than the vernacularization of Kurmanjî, and less around court life than that of Hawramî. However, it did include a number of didactic religious works: among the first texts written in Soranî are the Ehmedî, a small Arabic-Kurdish vocabulary written by Qadirî shaykh Ma'rûf Nodê for his son Ehmed, and the Eqîdetnamey kurdî by Mawlana Khalid Naqshbandi, a simple prose text setting out the basics of the faith for Naqshbandi laypeople in a language, or rather dialect, they could understand. Apparently, the Ehmed $\hat{\imath}$ gained a wide circulation: even today reprints are easily available. I have seen little evidence, however, that it was widely used in local medreses or hujras. Some local informants report that in Southern Kurdistan, both the Ehmedî and the Eqîdetnamey kurdî were used in hujras; but others claim that they were confined to schools with Qadirî and Naqshbandî affinities, respectively; moreover, these reports are not as consistent as those concerning Kurdish-language textbooks in the North. ${ }^{20}$ Apparently, the use of Kurdish-language textbooks was not as widespread or as systematic in Southern Kurdistan as in the North.

Thus far, I have encountered only one written source on Southern Kurdish medrese life: Hewrami (2008: 324-341) lists a small number of Kurdish- (and Persian-) language textbooks used in the hujras of Southern Kurdistan, but he does not indicate how widely these texts were used. His "first list," presumably corresponding to the first year, includes one Kurmanjî text, Ehmedê Xanî's Nûbihar, a Mewlûdnamey kurdî̀, and an Eqîdey îman. These may, but need not, have been written in Kurmanjî as well (possibly, Hewrami is referring here to Mullah Bateyî's Mewlûd and Xanî's Eqîde, respectively). Next, Hewrami lists Shaykh Ma'rûf Nodê's Ehmedî and an Eqîdey kurdî (the latter possibly to be identified with Mawlana Khalid's short text better known as the I'tiqâdname),

\footnotetext{
19 For more details, see Leezenberg, "Eli Teremaxi."

20 Interviews, Erbil, Sulaimaniya, Koya, July 2011, Spring 2012, August 2015, May 2016.
} 
and a number of works in Farsî, including an Isma cilname, the Pendî Attâr, the "Gulistan of Hafiz Shirazi" [sic], and a Persian-language work by shaykh Ma'rûf Nodê, the Çaydûde. In the second year, attention shifted to textbooks of Arabic grammar (sarf and nahw), starting with Jurjânî's and Birgevi's identically titled Awâmil; Hewrami's "second list" also includes a work on tasrîf by one Mullah Ali, possibly to be identified with 'Elî Teremaxî; but this is by no means certain. In later years, only Arabic-language books were read.

For the most part, however, the literate and literary elaboration of the Sulaimanî dialect - and, perhaps more importantly, its language-ideological elevation - appears to have been the work of poets such as Nâlî (d. 1855?), Sâlim (d. 1869), Kurdî (d. 1849), Mewlewî (d. 1882), Mehwî (d. 1909), and especially Hajî Qadir Koyî (d. 1897). As far as we can tell from their poems all of these were devout believers; but as poets, they did not operate primarily in medrese circles. It has been said that the rise of the Sulaimanî dialect was due in the first place to the patronage of the local Baban dynasty, and marginalized the neighbouring Erdelan court, and with it, presumably, the use of Hawramî; but this view cannot be maintained without substantial modification. Even in the city of Sulaimaniya, Hawramî continued to be used as a medium of poetic expression; thus, Mewlewî wrote his Dîwan, and a long aqîda poem, the Mardiyya, in Hawramî. In fact, the very first sample of printing in Kurdish, the trilingual Dîwan of Mawlana Khalîd Naqshbandî published in 1843 in Istanbul, included a small number of Kurdish-language poems, all of them in Hawramî.

In short, until well into the twentieth century there was little to suggest that Soranî was in the process of becoming a major language of education and administration. It was written by only a small number of local poets, and read by few more; whatever fame these poets enjoyed resulted from public oral recitation in local teahouses rather than printed books or periodicals. Rather, until World War I everything pointed to Kurmanjî as the main Kurdish variety of the future: it could boast a relatively extended and relatively widely known classical literary tradition and a continuous use in medreses; it was the main medium used in early periodicals such as Kurdistan, Rojî Kurd and Jîn; and it was the dialect of the poem that had come to be seen as the Kurdish national epic, Ehmedê Khanî's Mem û Zîn (first printed in Istanbul in 1919). This was a matter of authors using their own dialects rather than the conscious creation of a standard language: thus, several Kurmanjî journals printed Hajî Qadir Koyî's Soranî poems without any qualms, and a few texts in the Northwestern Zaza dialect were printed as well. The dramatic political developments in the aftermath of World War I, however, took an unexpected turn for the Kurds, with far-reaching linguistic consequences. 
The new political realities created by World War I called an abrupt halt to the development of the Kurmanjî dialect and provided unexpected opportunities for Soranî. In the emerging republic of Turkey initial promises concerning political autonomy and linguistic recognition for the Kurds were soon forgotten. A 1922 draft autonomy law still envisioned promoting and encouraging the use of Kurdish. However, by March 1924 the Kemalist elites promulgated a law demanding that only Turkish be used in law courts and prohibiting the use of Kurdish in schools and other public spaces. Likewise, 1924 law no. 430 on the unification of education (tevhîd-i tedrîsât kanunu) led to the closing of all medreses, which in the Kurdish-speaking regions had been the main institutional network for Kurdish vernacular learning. Although a good many rural Kurdish medreses continued to function clandestinely, these measures effectively put a stop to the development of the Kurmanjî dialect into a full-fledged medium for modern education, literature, and administration. Laws banning both the public and the private use of Kurdish remained in force for decades, and were only relaxed in the early 199os; until that time, the cultivation of Kurmanjî as a language of modern learning and literature was continued only by intellectuals in European exile.

Developments in mandate and monarchical Iraq ran a rather different course. The new territory of Iraq knew a great variety of Kurdish dialects; these are conventionally grouped together as varieties of Badînî or Badînanî spoken to the Northwest of the Zab river; and the Soranî varieties spoken further Southeast. The Badînan region counted few if any major urban centres; Sulaimaniya was by far the biggest Kurdish-majority city. ${ }^{21}$ Although not as openly assimilationist as the Kemalist elites in Turkey, successive Iraqi governments wavered between an accommodationist attitude towards Kurdish demands and an increasingly militant Arab nationalism. During the war, the British had tried to encourage anti-Ottoman nationalist feelings among the Kurds, as they had successfully done among the Arabs. Looking back on the period in a 1925 report, British official C.J. Edmonds wrote that during World War I "one of the devices adopted by the British officers in Kurdish territory for consolidating Kurdish national sentiment was the introduction of Kurdish as the written official language in place of the Turkish of Government offices and the Persian of private correspondence."22 Note that his words imply

\footnotetext{
21 The local elites in cities like Erbil, Kirkuk, and Mosul had long spoken, and to some extent continued to speak, Turkish.

22 Quoted in Hassanpour, Nationalism, 103.
} 
that at this stage, Turkish and Persian rather than Arabic were the main languages for public and private literate communication, respectively.

Following the British military occupation of Iraq, the League of Nations granted Great Britain a mandate over the country, explicitly intended to pave the way for Iraq's independence. Although the British mandate undoubtedly had a profound impact on Iraq as a whole and on the Kurds in particular, it is easy to overstate this influence at the expense of local actors. At the same time, however, there was an Iraqi government in Baghdad which can by no means be described as a British marionette; and, as we shall see, a number of Kurdish actors were likewise actively creating new social realities themselves rather than merely reacting to outside forces or, even worse, passively assimilating hegemonic influences.

As noted above, prior to 1918 virtually all Kurdish books and periodicals had been printed in the Kurmanjî dialect. But when in that year the vilayet of Mosul came under British control, the Sulaimaniya dialect quickly gained in prominence. It is not clear whether this shift to Soranî reflected a conscious policy on the part of the local British authorities, and if so, what were the reasons for it: no British documents specifically dealing with linguistic policies have come to light. However, there are a number of factors that may help to account for it. First, the vilayet did not include any of the traditional centres of Kurmanjî learning and letters such as Cizre, Diyarbakır, and Muks. The Kurmanjî-speaking area of Iraqi Kurdistan that had come under British control, the Badinan region, had rather fewer urban and princely centres, and apparently had less of a tradition of Kurdish-language learning than the regions further North. The major exception here, of course, was the court of Amadiya, where Ottoman traveller Evliya Çelebi had already observed considerable Kurdish-language literary activity in the seventeenth century. But this activity had declined in later times, especially after the Ottomans had abolished the emirate in the mid-nineteenth century. Second, the Sulaimaniya region had become more urbanized and more exposed to modern Ottoman education than the Badinan: it had relatively many modern schools, and was especially proud of the sole military school of Mosul province. As a result, relatively larger parts of the population had become acquainted with both the Ottoman Turkish language and with new Ottoman intellectual currents, in particular nationalism.

Prior to the British occupation, the Sulaimanî dialect had been used in writing almost exclusively for poetic purposes, with a few notable exceptions, such as Shaykh Hasan Qazi's Mewludname, Mawlana Khalîd's Eqîdetnamey kurdî, Shaykh Ma'rûf Nodî's Ehmedî, and a partial translation of Saadi's Golestan. In late Ottoman times Soranî Kurdish was used neither in education nor in new 
genres of writing such as journalism or novels. Thus, a 1926 British memorandum to the League of Nations states, not without justification, that "before the war, Kurdish was not used as a means of written communication, either private or official $[. .$.$] the development of the written language as a means of com-$ munication is entirely due to the efforts of British officials." ${ }^{23}$ Such comments may tempt us into concluding that the literate use of Soranî Kurdish, and by extension the existence of a language-based 'national sentiment' among Iraqi Kurds, is merely, or primarily, a creation of British imperialism. Such a conclusion, however, overstates the hegemony of imperial power and downplays local and longer-term dynamics, in particular the Kurdish vernacularizations of the eighteenth and nineteenth centuries and the formation of new Ottoman nationalisms during the Hamidian and Young Turk periods.

Initially, and in theory, British policies were clearly germane to both the linguistic and the political emancipation of the Kurds, but the practical implementation of these policies greatly depended on, and varied with, whoever was in charge. ${ }^{24}$ Among the most pro-Kurdish officials was Major Ely Banister Soane, who served as the British political officer in the Kurdish region from 1919 to 1921. Already in 1918 Soane had started editing and publishing the Kurdish-language journal Têgeyishtinî rastî ("Understanding the Truth") in Baghdad. In 1913 and 1919, he also published grammars of Kurdish that covered both the Kurmanjî and Soranî dialects. The paper served obvious propagandistic purposes: it consistently carried the claim that the Kurds were better off in a British-administered Iraq than in an Ottoman state headed by increasingly nationalist Turkish elites. After replacing major Noel as political officer, Soane settled in Sulaimaniya. His rule, though harsh, appears to have led to greater prosperity among the local population. He also seems to have encouraged greater autonomy for the region - something his superiors in Baghdad, let alone London, were not necessarily happy about. More relevant to our purposes, Soane also encouraged the official use of Soranî Kurdish, for instance by launching a new newspaper, Pêshkewtin ("Progress"). Reportedly, its use of written Kurdish for journalistic aims was at first mocked by local literate Kurds, but the paper quickly gained popularity. ${ }^{25}$ The paper, like its predecessor, Têgeyishtinî Rastî, used Soranî rather than Kurmanjî Kurdish, apparently

23 Quoted in Hassanpour, Nationalism, 105-106.

24 On British educational and linguistic policies in Iraq, with an eye for their occasionally capricious twists and changes, see Peter Sluglett, Britain in Iraq: Contriving King and Country (London: I.B. Tauris, 2007), Ch. 8, and Hassanpour, Nationalism, 103-118; 306-315. in David MacDowall, Modern History of the Kurds (London: I.B. Tauris, 1996²), 158-159. 
targeting Kurds already living in Iraq rather than those living on Turkish territory, and specifically targeting the urban Sulaimaniya population rather than the more rural Kurmanjî-speaking Kurds in the North of the vilayet. However, following the Cairo conference, where it had been decided to incorporate Southern Kurdistan into Iraq rather than making it an independent state, Soane was dismissed in 1921; he died a year later.

These vagaries point to a basic contradiction underlying British policies towards the Kurds in Iraq. On the one hand the British encouraged, or tolerated, Kurdish national sentiment as a means of countering Turkish claims on Mosul vilayet; on the other, they tried to contain Kurdish aspirations, primarily out of a concern to preserve the unity of the country ruled by King Faisal. Moreover, there were great differences between different segments of the British authorities: policymakers in London tended to uphold Woodrow Wilson's principle of self-determination, whereas officers in Baghdad, such as A.N. Wilson, preferred an Indian-style centralized colonial rule for Iraq.

A report by the League of Nations commission had made the inclusion of Mosul into Iraq conditional on the appointment of Kurdish officials in the vilayet and on the introduction of Kurdish in the regional administration, courtrooms, and schools; but neither the British authorities nor the Baghdad government did much to meet these conditions. In fact, after the 1925 League of Nations awarding of Mosul vilayet to Iraq, Britain tacitly abandoned its earlier promises of autonomy to the Kurds. Fond of laws as they were, the British tried to safeguard the status of Kurdish by stating their intention to enshrine it in a promised or planned "Local Languages Law," but for years no such law was actually drafted, let alone ratified. Hence, one should neither overstate the effect of this law nor overestimate the sovereign power it reflects or embodies. A British recommendation to the Iraqi government to establish a Kurdish translation bureau, intended to provide Kurdish-language textbooks and translations of legal texts, likewise remained a dead letter. In the spring of 1930, the government in Baghdad announced that it would allow Kurdish as an official language in the North; but this promise, like earlier ones made by the British, yielded few if any concrete measures.

It was not until May 1931 that the long-promised Local Languages Law was ratified, in anticipation of Iraq's admission into the League of Nations, and in reaction to continuing Kurdish agitation. ${ }^{26}$ In fact, Kurdish protests were at least as important in bringing the law into existence as British policymaking efforts. Clearly, British and Iraqi authorities saw the Languages Law 
as an alternative to - not to say a fig leaf for - earlier promises of autonomy or even statehood. It should be noted, incidentally, that this law only mentions the Arabic, Turkish, and Kurdish languages, and hence provides no legal basis for furthering the languages of smaller groups, such as (different kinds of) Aramaic, Armenian, and others. Moreover, except for article 8, which implicitly recognizes the existence of distinct forms of Kurdish in Sulaimaniya, Kirkuk, and Mosul governorates, the law apparently assumes Arabic, Turkish, and Kurdish as unproblematic givens or as essentially unitary phenomena, even though in fact this period witnessed fierce discussions concerning the appropriate official variety of all three languages.

It was clear to even the most casual observer that the British failure to honour earlier pledges concerning the use of Kurdish would lead to further unrest. Thus, C.J. Edmonds, who in later years would closely collaborate with Tawfîq Wahby on what was to become the first full-fledged Soranî-English dictionary (published in 1966), repeatedly expressed his frustration at the British mandate authorities' and the Iraqi government's unwillingness to honour earlier pledges concerning publication, education, and administration in Kurdish, for instance in a secret 1929 memorandum to the British High Commissioner. ${ }^{27}$ As a result, the late 1920 and early 1930 s witnessed an increasingly openly expressed Kurdish disaffection with British unwillingness to fulfil its promises and with the Baghdad government's reluctance to further the development of Kurdish.

The contradictions of British policies were painfully clear to local observers; the disagreements between the British and the (Sunni Arab-dominated) Iraqi government were even starker. The new Iraqi elites were increasingly virulent Arab nationalists; hence, the policies of the Baghdad government during the mandate and monarchical period appear to have been informed by the assimilationist kind of nationalism that could be found in the late Ottoman Balkans and in the early Republic of Turkey, even though in practice it was rather less successful in implementing these ideas. The government insisted on keeping Arabic at the very least as a second language at all stages of education - a policy it saw as essential to the political integration of Kurds into the new Iraqi state. In principle, the government favoured bilingual education in the first years of primary education; in practice, however, it did much to further Arabic and to thwart the development of Kurdish. Arab officials in Baghdad, keen on establishing an Iraqi national unity (a unity which, they tacitly assumed, was or had to be Arab and Sunni) rejected the introduction of Kurdish schools as 
of "no practical use." Behind such seemingly practical concerns, however, was a deep suspicion, if not outright hostility, towards any policy that hinted at catering to the ambitions of shaykh Mahmud Barzinji, the would-be king of Kurdistan, who was formally in exile but maintained good relations with several representatives of the British authorities. ${ }^{28}$

More generally, the development of an increasingly exclusivist and assimilationist Arab nationalism in Iraq during the 1920 and 1930 s did little to encourage the development of Kurdish as a written language of public communication. A leading role in this was to be played by the famous - or notorious - Sati al-Husrî, one of the pioneers of secular Arab nationalism, who during this period was in charge of education in Iraq as a whole. Although this is not the place for a detailed discussion of his views, al-Husrî has often been credited with a völkisch nationalism inspired by German romanticism, notably as a result of his translations of Fichte; but the assimilationist character of his nationalism cannot easily be explained from such alleged German influences. Instead, al-Husrî's ideas appear to have been shaped by the more militant national movements of Macedonia, where he lived from 1900 to $1909 .{ }^{29}$

Kurdish Non-State Actors and the Governmentalization of Kurdish

In short, neither the British mandate authorities nor Iraq's Sunni Arab rulers were unequivocally supporting, let alone encouraging, the development of Kurdish in monarchical Iraq. Instead, it was local Kurdish actors, most of them not or only indirectly linked to the Iraqi state, who brought about the development of Kurdish into a fully-fledged written language of modern communication. This process involved activities on several levels; we may see these as different governmentalizing gestures in that they all involved the production or reproduction of knowledge of a regimented Kurdish language as a political or governmental project.

\footnotetext{
28 Sluglett, Britain in Iraq, 125-127.

29 For a recent study on Arab nationalism in Iraq, which has revealingly little to say about Arab nationalist views of Kurds or other groups, see Peter Wien, Iraqi Arab Nationalism: Authoritarian, Totalitarian, and pro-fascist Inclinations, 1932-1941 (Abingdon/New York: Routledge, 2006). On al-Husrî, see Bassam Tibi's outdated but still useful study Arab Nationalism (London: Macmillan, 1981). For a fuller argument concerning the importance of al-Husrî's Macedonian years, see Leezenberg From Coffee House to Nation State (in preparation). Wien similarly argues that the influence of German national socialism on Iraqi Arab nationalism has been rather overstated in the literature.
} 
A first form of governmentalization of Kurdish was the creation of Kurdish schools, an effort which was clearly dependent on the Iraqi state for both official authorization and financial support. Despite paying lip service to the ideal of preparing Iraq for independence, the British mandate authorities never considered the education of a future ruling elite a policy priority. In fact, the 1923 Iraq Report stated that "it is neither desirable nor practicable to provide secondary education except for the select few."30 Except for a small number of dwindling Shiite centres of learning in the holy cities of Najaf and Kerbela, the Ottoman schools that had been established in Iraq just prior to the British occupation - few in number anyway - all had Turkish as their language of instruction and catered to Sunnis only. ${ }^{31}$ Apart from these modern state schools, there were an unknown number of hujras, or elementary Qur'anic schools, attached to local mosques. It was the British who replaced the Turkish-language schools with institutions where the language of instruction (at least for the lower classes) and the religious denomination taught varied with those of the majority of the pupils. Between 1923 and 1930 the number of Kurdish primary schools in Iraq rose from 6 to 28 , that is, from $3 \%$ to $9.6 \%$ of the total number of schools. Apparently, these Kurdish schools received hardly more state funding than the schools for the rather smaller Turcoman community. ${ }^{32}$

In the new schools, however, there was a strong emphasis on classical Arabic and on rote learning; moreover, there was an ongoing battle over what should be the extent of both Arabic and Kurdish instruction at primary and secondary levels. At one point, the government even tried to make the establishment of secondary schools in Erbil and Sulaimaniya conditional on the local population accepting Arabic as the language of instruction. ${ }^{33}$ After Iraq had been admitted into the League of Nations, these efforts at Arabization of the few Kurdish schools in the region intensified; in the 1940s, Kurdish was even removed from the curriculum altogether, not to be reintroduced until well into the 1950s. Clearly, the introduction of Kurdish into Iraqi schools was neither the creation of a sovereign Iraqi state nor the imposed product of British imperialism, but an aspect of a contested process of governing the Kurdish population, and a site for protracted struggle.

A second, and very much contested, way in which the Kurdish language was governmentalized was through a new linguistic regimentation: for the first

30 Quoted in Sluglett, Britain in Iraq, 194.

31 Sluglett, Britain in Iraq, 197.

32 Hassanpour, Nationalism, 311. I have come across few comments on or references to Turkish-language education in Iraq; even fewer of these are reliable or precise. Discussion of this topic will have to wait for another occasion.

Edmonds, secret report; quoted in Hassanpour, Nationalism, 314. 
time ever, local Kurds now set out to codify the grammatical rules of the Soranî variety of their language. Despite initial appearances, this aspect of governmentalization, too, resulted from a struggle against, as much as the exercise of, Iraqi state power. In 1923, the Iraqi Directorate of Education had commissioned Tawfiq Wahby to write a Kurdish grammar textbook for use in elementary schools. In order to better accommodate the particularities of Sulaimanî Kurdish, such as the rolled $/ \mathrm{r} /$, the velarized $/ \mathrm{l} /$, and the $/ \mathrm{o} /$, Wahby proposed a number of orthographic changes in the Arabic script; moreover, he also proposed writing the short /e/ sound. These and other suggestions, however, met with fierce opposition from the Directorate; apparently, its protests were driven both by religious Islamic and by purely secular Arab nationalist considerations. Thus, Sati 'al-Husrî, at that time director general of education in Iraq, was one of the main opponents of Wahby's proposed orthographic reforms. As a result, Iraqi state officials decided not to publish Wahby's textbook; it did not appear until 1929, in a private edition printed at the author's expense. Instead, the directorate proceeded to sponsor the publication of Sa'id Sidqi's Muxteser serf $\hat{u}$ nehwî kurdî (1928).

Besides orthographic differences, these two grammars display considerable methodological divergence: in a later interview with Amir Hassanpour, Wahby said that his grammar was modelled on a French grammar textbook by Larive and Fleury for use in elementary schools. ${ }^{34}$ But whereas Wahby's textbook was modelled on modern French grammars, Sidqi appears to have taken traditional Arabic grammars as his model; his textbook also employs the classical Arabic grammatical categories, beginning with terms such as sarf and nahw, instead of employing modern categories such as morphology and syntax. Thus, the rivalling political ideologies of Kurdish and Arab nationalism also found their expression in competing linguistic ideologies, and more concretely, in diverging grammatical and orthographic choices, without either of them being obviously or immediately hegemonic. Put differently: one cannot reduce the codification of Soranî Kurdish to the adaptation or internalization of modern Western grammatical categories, or to the passive assimilation of a Western philological orientalism assumed to be hegemonic in advance. Given the severely limited number of Kurdish schools, Sidqi's textbook was not widely used anyway; and, as noted in the early 1940s, Kurdish was removed from the primary school curriculum altogether. ${ }^{35}$

34 Amir Hassanpour, Sedeyek xebat le pênawî zimanî kurdî da: tîorî, siyaset $\hat{u}$ ideolojî (Sulaimaniya: Binkey Zhin, 2015), in particular ch. 4.

35 I am indebted to Lana Askari for securing a copy of Tawfîq Wahby's text; unfortunately, I have not been able to get a copy of Sidqi's grammar. 
A third aspect of the vernacularization-cum-governmentalization of Soranî Kurdish was the establishment of a corpus of Kurdish literature, which involved a new regimentation of texts written in Soranî. As before, Kurdish belles lettres were dominated by poetry, but new genres appeared as well, in particular the short story and, increasingly, drama - a genre especially fit for a low-literacy environment. The first 'proper' Kurdish novel, Ibrahim Ahmad's Janîgel, would not be written until after World War II, and would not be published until 1971. Likewise, the first locally produced history of Kurdish literature, Sajjadi's Mejuy edebî kurdî, was only published in 1956.

Thus, until at least World War II, the process of vernacularization of Soranî Kurdish continued to centre around poetry, with poets such as Pîremerd (d. 1950), Abdullah Goran (d. 1962), Fayîq Bêkes (d. 1948) and the Iranian Kurdish Hejar (d. 1991). The question of whether and to what extent these authors mark the birth of a 'modern' Kurdish literature is a moot one; I shall not address it here. ${ }^{36}$ Several of these poets, incidentally, were also involved in the writing of the first Kurdish readers used in local schools, and in the publications of the first Kurdish literary periodicals.

An important dimension of the creation of a Kurdish national literary corpus involved gathering the poems of poets who were being canonized, and which had until then been scattered among various journals or published as broadsheets to be recited at local teahouses. Thus, the 1920 and 1930 s witnessed the publication of first editions of the Dîwans of poets such as Mehwî (1922), Hajî Qadir Koyî (1925), Nalî (1931), Kurdî (1931), and Shaykh Riza Talabanî (1935).

Finally, the creation of a national Kurdish literature involved the translation of works between Kurdish dialects. Most importantly, during the 1930s, Pîremerd translated the Hawramî poems of authors such as Mewlewî, Besaranî, and Mawlana Khalîd into Soranî; it is in these Soranî renderings that Iraqi Kurdish school children have become acquainted with these poets until today. Another example of this appropriation is the promotion of Ehmedê Xanî's Mem û Zîn to the status of Kurdish national epic. In earlier times, the tragic tale of Mem and his beloved Zîn had circulated in both written and oral Kurmanjî versions in the Kurdish North, but it had never become as popular or even as well known - further South. Now, due in part to the praise heaped on Xanî by Hajî Qadir Koyî, the poem acquired a canonical national status. In 1935, Pîremerd published the first stage adaptation of the story, and numerous others were to follow. Finally, in 196o, Hejar rendered Xanî's poem into modern Soranî, deleting or weakening much of the original's mystic contents in the process. As far as I know few if any of these efforts received any appreciable

36 But cf. Farangis Ghaderi, "The challenges of writing Kurdish literary history: Representation, Classification, Periodisation," Kurdish Studies 3,1 (2015): 3-25. 
amount of Iraqi state support in the form of either subsidies for the authors, officially sanctioned publication, or government-sponsored distribution of books.

But there also appears to have been resistance against the promotion of Soranî from a very different corner: that of Kurmanjî, or Badînî, speakers. The exact sociolinguistic relation between the different varieties of Kurdish in Iraq is, in fact, a long-neglected aspect of this protracted linguistic and languageideological struggle. Local Kurdish activists appear to have assumed as a matter of course that the Kurds should have a single official language variety, and that this variety should be based on the Sulaimaniya dialect. Thus, in a 1931 petition protesting against the Local Languages Law, Kurdish historian and Sulaimaniya representative Muhammad Amîn Zakî specifically objected against article 8 of the law, which allowed for a different "form" of "type" of Kurdish to be used in the Qadhas of Mosul liwa. Skating over the "slight differences" between what he, rather idiosyncratically, called the "Western" and the "Eastern" Kurmanjî dialects (respectively, Badînî and Soranî), and appealing to the authority of science rather than states, Zakî wrote:

In selecting the eloquent dialect according to scientific principles, the Eastern Kurmanjî dialect must be accepted, since it is close to the eloquent Mukri dialect, and must be made the official language of all the offices and institutions existing in Iraqi Kurdistan. ${ }^{37}$

Clearly, this plea for a unified Kurdish language was driven by languageideological and political assumptions as much as purely linguistic or scientific ones. It proved powerless, however, against the divide-and-rule tactics of the Iraqi government, which had been making serious efforts at arabising the Kurdish-speaking areas of Mosul liwa. But there are also indications that sometimes, Badînî speakers themselves indicated a preference for Arabic over Soranî Kurdish as a language of instruction and administration. ${ }^{38}$

We know very little about linguistic attitudes and activities in Badînan during this period. It turns out that a local intellectual, one Hama Sacîd Duhokî, wrote a Kurmanjî grammar in 1932, possibly as a complement or alternative to existing Arabic and Sorani Kurdish school grammars; but this work was not published until 1998..$^{39}$

37 M.A. Zakî, Dû teqellay bêsûd (Baghdad 1935), quoted in Hassanpour (1992: 157).

38 Cf. Hassanpour (1992: 158-9).

39 Interview, Mohammad Abdullah, Duhok, April 2019; see also Muhammad Abdullah, "Rêzimana mela Mihemmed Sê̂̀ê Duhokî," Metîn 77 (1998): 50-65. I hope to explore these matters, and Duhokî's grammar, in more detail on a future occasion. 
In short, the vernacularization of Soranî and its promotion to an official language were long and highly contested processes, which largely developed in spite of, as much as because of, both British imperialist rule and Iraqi state power. Hence, as noted above, governmentalization should not be confused with the exercise of sovereign power by the state; and indeed, the governmentalization of Soranî Kurdish was the result of resistance against, rather than the influence or imposition of, either Iraqi state power or British imperial hegemony. Hence, the suggestion that language-based Kurdish nationalism - or, for that matter, any post-Ottoman nationalism - is the product of Western imperialism, or involves a form of 'self-orientalization,' that is, the internalization of romantic-nationalist categories of philological orientalism assumed to be hegemonic, is at best a serious oversimplification and at worst an egregious error. It not only overstates the dominance and coherence of British influence in Iraq, let alone areas not under direct British control, but also ignores the process of vernacularization that started virtually all over the Ottoman empire in the eighteenth century, that is, prior to any political, economic, or cultural influence or domination of Western capitalist powers in the region. Local actors were by no means forced to reproduce any hegemonic discourse. Thus, Wahby's Soranî grammar was indebted not to British orientalism but to a French school textbook; its main rival, Sidqi's 'official' grammar, was informed not by modern Western orientalism but by the categories of premodern Arabic grammar. Second, one should pay due attention to the new internal dynamic triggered by, in particular, the 1877-1878 Russo-Turkish war and the ensuing territorial struggle between rivalling national movements in the Balkans - a struggle that reverberated throughout the empire. Thus, Ottoman and postOttoman nationalisms owe as much to these - partly Russian-inspired - secretive, revolutionary and militant Eastern European nationalisms as to the more liberal French-inspired patriotism and the Prussian-inspired forms of cultural nationalism that are usually claimed to have emanated from Western and Central Europe. Third, and most importantly, one should not overlook the crucial role played by early modern forms of vernacular learning in the redefinition of peoples in primarily linguistic terms, and hence in the rise of new language-based nationalisms in the late Ottoman empire and its successor states. These points may also be worth keeping in mind when one is studying other forms of vernacularization and nationalism in the wider region. 
Considerations of space preclude a fuller discussion of developments in republican Iraq, especially the dramatic and destructive policies pursued by the Baathist regime (1968-2003).$^{40}$ After taking power in 1968, the Baathist regime, alongside its more widely published Stalinist personality cult surrounding Saddam Hussein and the use of terror as a prime instrument of government, also modelled its attitudes and actions vis- $a$-vis the Kurds and other minorities on early Soviet nationality policies. This seemingly accommodating attitude, however, was difficult to reconcile with the Baathist constitution, which declared Iraq to be an Arab state, and with the Baathists' increasingly assimilationist, racialized and violent Arabism. ${ }^{41}$

After the 1991 uprisings, however, a radically new linguistic landscape emerged in the North of Iraq. Current linguistic realities in the Kurdistan Region are sufficiently complex to merit a brief mention. The standing policy of Arabization came to an abrupt halt in the wake of the 1991 uprisings and the subsequent establishment of a de facto, and since 2005 de jure, autonomous region in Northern Iraq. The Kurdistan Regional Government (KRG), however, has never developed any language policy worthy of the name. Since 1991, the use of Kurdish in school textbooks, administration and broadcasting has really taken off, but this has been a rather haphazard, improvised, and localized process. Soranî was widely, if implicitly, recognized as the standard, but in practice, most authors wrote the subvariety of their own native area.

Since 1993, the Kurdish regional authorities have allowed education in a standardized form of Aramaic in primary and secondary schools; attempts to introduce this language as a topic for university study, however, have met with fierce resistance. Reportedly, its opponents expressed the fear that this move would encourage Christian missionary activity in the region. ${ }^{42}$ Turcoman has likewise been allowed as a language of instruction in local schools. No similar provisions were made, however, for any of the locally spoken Hawramî or Goranî varieties, even those spoken by religious minority communities; the Kakaîs around Tawûq in the Kirkuk governorate and on the Iraqi-Iranian border near Halabja use a Hawramî variety they call Maço ("I say"), whereas the Shabak, who used to live in the Ninawa plain East of Mosul until the 2014 ISIS

40 For more detailed accounts of recent developments cf. Sheykholislami (2012) and Khalid Hewa Saleh, The Language and Politics of Iraqi Kurdistan: From the 1991 Uprising to the Consolidation of a Regional Government Today. Lambert Academic Publishing, 2015.

41 On Kurdish policies language pursued by the Baath, see Hassanpour (1992), especially 119-125 and 316-331.

42 Interviews, local university teachers, Erbil, August 2015; Assyrian spokesmen, May 2017. 
offensive, speak the closely related vernacular of Shabakî. Apparently, local Kurdish authorities of both KDP and PUK have been reluctant to encourage the literate use of these dialects; nationalists often express a fear of encouraging divisions among the Kurds by allowing such dialects to develop. Recent developments in official ideology and behaviour also point to an increasingly strict and narrow conception of Kurdishness on the part of the ruling power elites. ${ }^{43}$

But it was party politics rather than the aspirations of linguistic minorities that most threatened the unity and stability of the region. Reportedly, in a reaction to the years of infighting between KDP and PUK, the KDP administration approved the introduction of the Arabic-script Badînî dialect in elementary schools in the Duhok governorate in 1998; and in 2009, the Duhok Directorate of Education changed the language of the first three years of high school to Badînî as well, bypassing the Kurdish Academy, which in theory was the authority to make such decisions. ${ }^{44}$

Thus, the realities created by party politics are at odds with widely shared Kurdish nationalist dreams, which have long been - and continue to be - informed by a "one nation, one language" ideology. Numerous works have appeared sketching out proposals for a unified Kurdish language, which is occasionally jokingly referred to as "Sormanji," but none of these proposals have met with wide acceptance. Reportedly in 2009 the regional Ministry of Education tried to introduce school textbooks in a unified Sormanji, but these attempts met with fierce opposition, in particular in the Badinan region, and hence were quietly withdrawn. ${ }^{45}$

In the everyday practice of broadcasting, numerous neologisms appear to have been coined that in practice have led to a convergence between Kurmanjî and Soranî. Thus, the stumbling blocks for linguistic unification were, and remain, of a political rather than a linguistic nature: conversely, differences of vocabulary, pronunciation, and orthography are very quickly given a political significance. As a result, any attempt to propose, let alone impose, a single language variety as a supraregional standard is immediately perceived as an attempt by a specific political party to achieve a hegemonic status.

Two anecdotal examples may indicate how differences in pronunciation, vocabulary, and writing system have become heavily politicized. On one occasion, after a lecture at a university in Erbil, a student asked me if I was a PKK sympathizer, since I had been showing my audience a Kurdish text sample in

43 Interviews, anonymous local informants, Erbil, May 2016.

44 Khoshnaw (2013: 363-371), quoted in Saleh, The Language and Politics: 29.

45 Cf. Saleh, The Language and Politics, 47-48. 
the Latin alphabet. On another, I was told of attempts to create a centre for Women's Studies in a local university, which ran into trouble when people realized that there was no politically neutral word for "woman": using either of the two most current terms, afret and jin, would imply or suggest an affinity with one of the two main Kurdish parties. The university staff briefly contemplated using the politically more neutral, but awkward, term "ladies" (xanimakan), before settling on the foreign loan word gender. The latter term, in turn, was crudely mocked by local Islamists, who referred to the "centre for gândâr (lit., 'fuckers') studies."

The politicization of plans to promote any one variety of Kurdish to a universal Kurdish standard came to a head in 2008, when a number of (mainly Iraqi) Kurdish intellectuals, echoing Zakî and others in earlier decades, presented a petition to regional president Barzani, asking for the Sulaimaniya dialect to be promoted to the linguistic standard not only for the Kurdistan region in Iraq, but for all Kurds. The proposal, never very realistic in the first place, provoked a heated debate, with accusations of authoritarianism and sowing linguistic discord flying back and forth. ${ }^{46}$ Significantly, the signatories of the 2008 petition did not ask the regional government to change social realities by any linguistic policies, but merely to recognize in law a social reality that, they claimed, had already come about: partly as a result of its recognition in the 2005 Iraqi constitution, they reasoned, Soranî was no longer a regional or local dialect but represented the Kurdish language as a whole. ${ }^{47}$ Equally significantly, the Kurdish Academy in Erbil, in theory the region's highest authority on the Kurdish language, was neither invited to join in these debates, nor does it appear to have taken any proactive stance itself.

The 2008 petition flew in the face of linguistic realities characterized by the widespread, and enduring, proliferation of dialects. Other attempts at creating a unified and/or standardized Kurdish language have remained equally unsuccessful. In 2011, a linguistic conference was held in Erbil; another one was organized in Diyarbakır in the following year. However, the participants in these conferences were unable to reach any consensus; the latter conference in particular was perceived - and accordingly criticized - as heavily politicized. Even in the Kurdistan Region of Iraq, a relatively compact area under nominally unified - Kurdish control since 1991, Kurdish has effectively become

$46 \quad$ For a brief overview, see Hassan Ghazi, "Language standardisation and the question of the Kurdish varieties: The language debate in Iraqi Kurdistan." Paper presented at the International Conference The Kurds and Kurdistan: Identity, Politics History, University of Exeter, UK, 2009; cf. also Saleh, The Language and Politics. 
a bi-standard language. The Kurmanjî spoken and written in Turkey, being written with Latin characters, cannot be reduced to written Badînî or Soranî. Hence, even irrespective of the different Zaza and Hawramî varieties Kurdish is at present at least a three-standard language: Latin-character Kurmanjî is used among Kurds in Turkey and Syria, and Arabic-character Badînî and Soranî among Kurds in Iraq and Iran.

\section{Bibliography}

Abdullah, Muhammad. "Rêzimana mela Mihemmed Seîdê Duhokî," Metîn 77 (1998): $5^{0}-65$.

Ahmed, Shahab. What is Islam? Princeton NJ: Princeton University Press, 2016.

Bahner, Werner. Das Sprach- und Geschichtsbewusstsein in der rumänischen Literatur von $1780-1880$. Berlin: Akademie-Verlag, 1967.

Dabashi, Hamid. The World of Persian Literary Humanism. Cambridge MA: Harvard University Press 2012.

Dallal, Ahmad. Islam before Europe: Traditions of Reform in Eighteenth-Century Islamic Thought. Chapel Hill: University of North Carolina Press, 2018.

Elsie, Robert. "Albanian Literature in the Moslem Tradition: Eighteenth and Early Nineteenth Century Albanian Writing in Arabic Script." Oriens 33 (1992): 287-306.

Foucault, Michel. Securité, territoire, population: Leçons au College de France, 1978-1979. Paris: Gallimard/Seuil, 2004.

Fragner, Bert. Die 'Persophonie': Regionalität, Identität, und Sprachkontakt. Berlin: Das arabische Buch, 1999.

Ghazi, Hassan. "Language standardisation and the question of the Kurdish varieties: The language debate in Iraqi Kurdistan." Paper presented at the International Conference The Kurds and Kurdistan: Identity, Politics History, University of Exeter, UK, 2009.

Hassanpour, Amir. Nationalism and Language in Kurdistan, 1918-1985. San Francisco: Mellen Research University Press, 1992.

Hassanpour, Amir. Sedeyek xebat le pênawî zimanî kurdî da: tîorî, siyaset $\hat{u}$ îdeolojî. Sulaimaniya: Binkey Zhin, 2015 .

Hewramî, Heme Kerîm. Mêjûyy perwerde û xwêndin le hucrekanî Kurdistan da. Erbil: Çapxaney Wezaretî Roshenbînî, 2008.

Hodgson, Marshall. The Venture of Islam, vol. 2: The Expansion of Islam in the Middle Period. Chicago: University of Chicago Press, 1974.

Kemura, Seifuddin \& Vladimir Corovic. Dichtungen bosnischer Moslims aus dem XVII., XVIII., und XIX. Jahrhundert. Sarajevo, 1912. 
Leezenberg, Michiel. "Elî Teremaxî and the Vernacularization of Medrese Learning in Kurdistan." Iranian Studies 47 (2014): 713-733.

Leezenberg, Michiel. "The Vernacular Revolution: Reclaiming Early Modern Grammatical Traditions in the Ottoman Empire." History of Humanities 1,2 (2016): 251-275.

Leezenberg, Michiel. From Coffee House to Nation State: The Rise of National Languages in the Ottoman Empire (in preparation).

MacDowall, David. Modern History of the Kurds (2nd ed.). London: I.B. Tauris, 1996.

MacKenzie, David N. “The Origins of Kurdish.” Transactions of the Philological Society (1961) 68-8o.

Mackridge, Peter. Language and National Identity in Greece, 1766-1976. Oxford: Oxford University Press, 2009.

Mardin, Serif. "Some Notes on an Early Phase in the Modernization of Communication in Turkey." Comparative Studies in Society and History 3 (1961): 250-271.

Minorsky, Vladimir. "The Gûrân.” BSOAS XI (1943): 75-103.

Muhammad, Kamal Ra'uf. Eqîdey 'îman - eqîdey kurdî - lûbubel-'eqâyîd. Erbil: Aras, 2004.

Nichanian, Marc. Ages et usages de la langue arménienne. Geneva: Éditions Entente, 1989.

Pollock, Sheldon. "Cosmopolitan and Vernacular in History." Public Culture 12 (2000): 591-625.

Pollock, Sheldon. The Language of the Gods in the World of Men: Sanskrit, Culture, and Power in Premodern India. Berkeley/Los Angeles/London: University of California Press 2006.

Pollock, S., ed. Forms of Knowledge in Early Modern Asia: Explorations in the Intellectual History of India and Tibet, 1500-180o. Durham NC: Duke University Press 2011.

Pollock, S., B.A. Elman, \& K.K. Chang, eds. World Philology. Cambridge MA: Harvard University Press, 2015.

el-Rouayheb, Khaled. Islamic Intellectual History in the Seventeenth Century: Scholarly Currents in the Ottoman Empire and in the Maghreb. Cambridge: Cambridge University Press, 2016.

Saleh Khalid, Hewa. The Language and Politics of Iraqi Kurdistan: From the 1991 Uprising to the Consolidation of a Regional Government Today. Lambert Academic Publishing, 2015 .

Sheykholislami, Jaffer. "Language Policy and Planning: Identity and Rights in Iraqi Kurdistan.” In Minority language in today's global society, vol. 2, edited by G. Kunsang, A. Snavely and T. Shakya (New York, NY: Trace Foundation, 2012), 106-128.

Sidqi, Sa'id. Muxteser serf û nehwî kurdî. Baghdad: Najah Press, 1928.

Sluglett, Peter. Britain in Iraq: Contriving King and Country. London: I.B. Tauris, 2007. 
Tibi, Bassam. Arab Nationalism. London: Macmillan, 1981.

Wahby, Tawfîq. Destûrî Zimanî Kurdî. Baghdad: al-Haditha Publishers, 1929.

Wien, Peter. Iraqi Arab Nationalism: Authoritarian, Totalitarian and Pro-fascist Inclinations, 1932-1941. London: Routledge, 2006.

Xanî, Ehmedê. Mem û Zîn (ed. J. Dost). Avesta Yayınları 2010 [1695]. 